\title{
Stratum Lacunosum-Moleculare Interneurons of Hippocampal CA1 Region. II. Intrasomatic and Intradendritic Recordings of Local Circuit Synaptic Interactions
}

\author{
Jean-Claude Lacaille ${ }^{1, a}$ and Philip A. Schwartzkroin ${ }^{1,2}$ \\ Departments of 'Neurological Surgery and 'Physiology and Biophysics, University of Washington, Seattle, Washington \\ 98195
}

\begin{abstract}
Simultaneous intracellular recordings were obtained from stratum lacunosum-moleculare (L-M) interneurons and CA1 cells, and their local circuit synaptic interactions were examined. Synaptic interactions with pyramidal cells were evaluated in both intrasomatic and intradendritic pyramidal cell recordings. Stimulation of L-M interneurons evoked smallamplitude IPSPs in $21 \%$ of intrasomatic ( $9 / 42$ cell pairs) and in $26 \%$ of intradendritic $(11 / 43)$ pyramidal cell recordings. The IPSP mean peak amplitude was $0.91 \mathrm{mV}$ for intrasomatic and $0.67 \mathrm{mV}$ for intradendritic recordings. IPSPs had slow onset and decay (approximately 80-90 $\mathrm{msec}$ ), decreased in amplitude with membrane hyperpolarization, and were not associated with any apparent change in input resistance. No physiologic evidence of synaptic connections was found from pyramidal cells to L-M interneurons. Inhibitory synaptic interactions were also seen between L-M interneurons and stratum pyramidale interneurons ( 2 of 4 cell pairs). The IPSPs recorded in pyramidale interneurons were similar to the IPSPs recorded in pyramidal cells. During simultaneous recordings, L-M interneurons were activated at a shorter latency, i.e., in a feedforward manner with respect to pyramidal cells. Thus, L-M interneurons may mediate feedforward Inhlbitlon of CA1 pyramidal cells. The L-M interneuron-evoked IPSPs in pyramidal cells share some characteristics of the late IPSP recorded in CA1 pyramidal cells and may therefore contribute to this component of the IPSP.
\end{abstract}

Despite the large amount of anatomical and morphological information available on the numerous types of local circuit neurons (interneurons) of the hippocampus (Ramon y Cajal, 1911; Lorente de No, 1934; Ribak et al., 1978; Tombol ct al., 1979; Somogyi et al., 1983; Roberts et al., 1984), much less is known of their specific physiology (Andersen et al., 1969; Schwartz-

Received May 26, 1987; revised Sept. 18, 1987; accepted Sept. 23, 1987.

This work was supported by National Institutes of Health, National Institute of Neurological and Communicative Disorders and Stroke Grants NS 15317 and NS 18897. J.-C.L. was partially supported by a NATO Science Fellowship from the Natural Sciences and Engineering Research Council of Canada and by a Postdoctoral Fellowship from Fonds de la Recherche en Santé du Québec. P.A.S. is an affiliate of the Child Development and Mental Retardation Center, University of Washington.

Correspondence should be addressed to Professor Philip A. Schwartzkroin, Department of Neurological Surgery, RI-20, University of Washington, School of Medicine, Seattle, WA 98195.

a Present address: Département de physiologie, Centre de recherches en sciences neurologiques, Faculté de Médecine, Université de Montréal, Montréal, Québec, Canada $\mathrm{H} 3 \mathrm{C} 3 \mathrm{~J} 7$.

Copyright (C) 1988 Society for Neuroscience $0270-6474 / 88 / 041411-14 \$ 02.00 / 0$ kroin and Mathers, 1978; Knowles and Schwartzkroin, 1981a; Lacaille et al., 1987; Lacaille and Schwartzkroin, 1988). With the development of the brain slice technique (Skrede and Westgaard, 1971), in which the intrinsic circuitry of the hippocampus is relatively conserved, it has been possible to apply physiological and anatomical methods in concert to characterize subclasses of hippocampal interneurons. Thus, 2 types of hippocampal interneurons, the basket cells and the oriens/alveus $(\mathrm{O} / \mathrm{A})$ interneurons, have been shown to have distinctive nonpyramidal intracellular response characteristics (Schwartzkroin and Mathers, 1978; Knowles and Schwartzkroin, 1981a; Lacaille et al., 1987). Intracellular staining of these physiologically identified interneurons confirmed their nonpyramidal nature and their respective interneuron type (Schwartzkroin and Mathers, 1978; Schwartzkroin and Kunkcl, 1985; Lacaillc ct al., 1987). Insights into the role of these 2 types of interneurons in the local circuitry of CAl region has been obtained using simultaneous intracellular recordings from pyramidal cells and physiologically identified interneurons and examining their mutual interactions. Both types of interneurons can receive direct EPSPs form CAI pyramidal cells (Knowles and Schwartzkroin, 1981a; Lacaille et al., 1987). In turn, both basket cells and $\mathrm{O} / \mathrm{A}$ interneurons can directly produce IPSPs in CA1 pyramidal cells (Knowles and Schwartzkroin, 1981a; Lacaille et al., 1987). These interneurons are also activated by hippocampal afferents in a feedforward manner with respect to CA1 pyramidal cells (Schwartzkroin and Mathers, 1978; Knowles and Schwartzkroin, 1981a; Buzsaki and Eidelberg, 1982; Frotscher et al., 1984; Lacaille et al., 1987).

Morphologically, basket cells and $\mathrm{O} / \mathrm{A}$ interneurons appear to make inhibitory synaptic contacts with pyramidal cells. With electron microscopy, HRP-filled, physiologically identified basket cells and $\mathrm{O} / \mathrm{A}$ interneurons have been found to make Type II symmetric synaptic contacts, characteristic of inhibitory synapses, with pyramidal cells (Schwartzkroin and Kunkel, 1985; Lacaille et al., 1987). Therefore, it appears that both basket cells and $\mathrm{O} / \mathrm{A}$ interneurons mediate feedforward and feedback inhibition of CA1 pyramidal cells. Since interneurons similar to basket cells and $\mathrm{O} / \mathrm{A}$ interneurons (although not physiologically identified specifically as such) are immunoreactive for GABA (Gamrani et al., 1986) and GAD (Ribak et al., 1978; Kunkel et al., 1986), this feedforward and feedback inhibition is likely to be GABA mediated (Alger and Nicoll, 1982a, b).

In the present paper we have used similar methods to determine the role in hippocampal circuitry of a third group of interneurons, the stratum lacunosum-moleculare (L-M) interneurons of CAl region, which we have recently characterized 
physiologically and morphologically (Lacaille and Schwartzkroin, 1987). Physiologically, L-M interneurons display intracellular response characteristics that are clearly nonpyramidal but that are distinctly different from basket cells and $\mathrm{O} / \mathrm{A}$ interneurons (Lacaille and Schwartzkroin, 1988) (see also the recent work of Kawaguchi and Hama, 1987). Morphologically, L-M interneuron dendrites arborize mostly in strata lacunosummoleculare and radiatum but also sometimes in stratum oriens (Ramon y Cajal, 1911; Lorente de No, 1934; Lacaille and Schwartzkroin, 1988). The axons of these interneurons also course in strata lacunosum-moleculare, radiatum, and pyramidale. An additional characteristic of L-M interneurons is that both dendritic and axonal processes cross the hippocampal fissure and course in stratum moleculare of the dentate gyrus (Lacaille and Schwartzkroin, 1988). To evaluate the functional role of L-M interneurons in the hippocampal CA1 region, we have cxamincd the mutual interactions between $L-M$ interneurons and CAl pyramidal cells in guinea pig hippocampal slices with paired intracellular recordings. Since L-M interneuron axons arborize in stratum radiatum as well as in stratum pyramidale, we have examined such interactions between $\mathrm{L}-\mathrm{M}$ interneurons and both intrasomatically and intradendritically recorded CA1 pyramidal cells. Because L-M axons also apparently terminate in the dentate gyrus, we have obtained intracellular recordings from L-M interneurons and granule cells, and tested their synaptic interconnections.

\section{Materials and Methods}

Slices. Hippocampal slices were obtained from Hartley guinea pigs (200$300 \mathrm{gm}$ ). The preparation and the in vitro maintenance of hippocampal slices were as previously described (Schwartzkroin, 1981; Lacaille et al., 1987; Lacaille and Schwartzkroin, 1988). Briefly, following decapitation and rapid dissection of the hippocampus, transverse hippocampal slices (500 $\mu \mathrm{m}$ thick) were obtaincd with a tissuc chopper. When longitudinal slices were used, they were obtained from the middle third of hippocampus along the septotemporal axis. Slices were placed on a nylon net in a gas-fluid interface chamber. Their undersides were bathed in artificial cerebrospinal fluid (ACSF) containing (in $\mathrm{mM}$ ): $\mathrm{NaCl}, 124 ; \mathrm{KCl}$, 5; $\mathrm{NaH}_{2} \mathrm{PO}_{4}, 1.25 ; \mathrm{MgSO}_{4}, 2 ; \mathrm{CaCl}_{2}, 2 ; \mathrm{NaHCO}_{3}, 26 ;$ and dextrose, 10. The ACSF was continuously oxygenated $\left(95 \% \mathrm{O}_{2}-5 \% \mathrm{CO}_{2}\right)$, heated to $35.5 \pm 0.5^{\circ} \mathrm{C}$, and perfused at a rate of $1 \mathrm{ml} / \mathrm{min}$. The upper surface of slices was exposed to a warm, humidified atmosphere $\left(95 \% \mathrm{O}_{2}-5 \% \mathrm{CO}_{2}\right)$.

Intracellular recordings. Intracellular responses were recorded with micropipettes filled with $4 \mathrm{M}$ potassium acetate and $0.01 \mathrm{M} \mathrm{KCl}$ (resistance in tissue, 50-100 M 2 ). Intracellular recordings from I-M interneurons were obtained by lowering the microelectrode in stratum lacunosum-moleculare near the stratum radiatum border as previously dcscribed (Lacaille and Schwartzkroin, 1988). Intracellular responses were amplified with a NeuroData dual-channel intracellular amplifier (IR-283), displayed on a cathode ray oscilloscope, digitized with a NeuroCorder (DR-484), and stored on digital tape for later retrieval and analysis with a microcomputer (Norland 3001/DMX). Intracellular stimulation was produced via a bridge circuit. Bipolar electrical stimulation of afferent fibers was done with resin-coated electrolytically etched tungsten microelectrodes placed under visual guidance and using a constant-current stimulus isolation unit (World Precision Instruments).

Stable impalements of neurons in L-M were obtained and their properties examined as previously described (Lacaille and Schwartzkroin, 1988). These cells displayed intracellular response profiles characteristic of identified L-M interneurons (large-amplitude, relatively long-duration action potentials; high input resistance; large-spike afterhyperpolarization; little frequency adaptation in response to depolarizing current pulses; Lacaille and Schwartzkroin, 1988). A subset of these interneurons (15 of 37) was used in a previous report of intracellular response characteristics of L-M interneurons (Lacaille and Schwartzkroin, 1988).

Paired intracellular recordings. Following a stable intracellular penetration of an L-M interneuron, intrasomatic recordings from CAl pyramidal cells were obtained by advancing another recording microelectrode in stratum pyramidale. When a stable penetration of a pyramidal cell was obtained, the responses of this cell pair were examined for mutual interactions. A train of action potentials was produced in the $\mathrm{L}-\mathrm{M}$ interneuron with a $100 \mathrm{msec}, 0.5 \mathrm{nA}$ intrasomatic depolarizing current pulse. The voltage response of the pyramidal cell was examined at the same time for the presence of postsynaptic potentials (PSPs). Possible connections in the reverse direction were then evaluated by eliciting a burst of action potentials in the pyramidal cell $(100 \mathrm{msec}$, $0.5 \mathrm{nA}$ intrasomatic current pulse) and examining the voltage response of the interneuron at the same time for PSPs. In many instances, a number of traces were averaged using a signal averager (Norland 3001/ DMX) to minimize background noise.

A similar procedure was used for paired intracellular recordings between L-M interneurons and CAl pyramidal cell dendrites. However, the microelectrode for intradendritic recording was lowered in stratum radiatum $250-400 \mu \mathrm{m}$ away from stratum pyramidale (toward stratum lacunosum-moleculare). Stable intradendritic recordings were different from pyramidal and nonpyramidal intrasomatic recordings, as described by others (Schwartzkroin and Mathers, 1978; Wong et al., 1979; Benardo et al., 1982; Masukawa and Prince, 1984). With rheobasic current injection, single action potentials resembling intrasomatic action potentials were recorded. With higher current intensity $(0.2-0.6 \mathrm{nA})$, multiple, fractionated spikes of variable amplitude and duration were evoked. Intracellular Lucifer yellow (LY) injection confirmed the intradendritic nature of these recordings.

Since L-M interneuron axons also innervate the dentate gyrus, we have obtained paired intracellular recordings from L-M interneurons and dentate gyrus granule cells. In these experiments, the second recording microelectrode was advanced through the granule cell layer of the upper blade of the dentate gyrus. Following stable impalement of a granule cell, the responses of the cell pair were examined for mutual interconnections.

When inhibitory postsynaptic potentials (IPSPs) were observed between cell pairs, the peak amplitude, peak latency, and decay of the average IPSP (10-25 individual traces) were measured at resting membrane potential. Peak amplitude was taken as the difference between peak hyperpolarization (excluding capacitative coupling artifacts) and resting membrane potential. Peak latency was measured as the difference in time between the peak of the first action potential (in the presynaptic cell) and the peak amplitude of the IPSP (in the postsynaptic cell). Time to recover from peak amplitude to resting membrane potential was taken as time to decay.

LY intracellular staining. In some instances L-M interneurons or CA1 pyramidal cells were intracellularly labeled with $L Y$. Recording micropipettes were filled with $4 \% \mathrm{LY}$ (Lucifer yellow $\mathrm{CH}$, Aldrich) in $1 \mathrm{M}$ LiCl (Stewart, 1978; Lacaille et al., 1987; Lacaille and Schwartzkroin, 1988). The LY die was injected intracellularly with steady hyperpolarizing current $(-0.5$ to $-1.0 \mathrm{nA}$ for $5-10 \mathrm{~min})$. Slices containing $L Y$ filled cells remained undisturbed in the chamber for $10 \mathrm{~min}$ following injection. They were then placed between 2 filter papers in a petri dish containing fixative ( $3 \%$ paraformaldehyde lysine periodate). Following 2-4 hr in fixative, slices were transferred and stored in phosphate buffer (PB; $0.1 \mathrm{M}, \mathrm{pH} 7.4$ ). Prior to sectioning, slices were sunk in $30 \%$ sucrose PB. Slices were sectioned (30-70 $\mu \mathrm{m}$ thick) on a freezing microtome. Sections were cleared in a series of alcohols, air-dried, and coverslipped in $5 \%$ glycerol in propyl gallate. Sections were examined and photographed on a Leitz Dialux 20 epifluorescence microscope equipped with appropriate filters. Major hippocampal subdivisions (Ramon y Cajal, 1911) could easily be distinguished during fluorescence microscopy. Drawings of the LY-filled neuron and its processes were made to assist with localization within CAl region.

\section{Results}

We have obtained stable intracellular recordings from $37 \mathrm{~L}-\mathrm{M}$ interneurons. We have tested for possible synaptic interactions between these L-M interneurons and $49 \mathrm{CAl}$ pyramidal cell intrasomatic recordings, $46 \mathrm{CA} 1$ pyramidal cell intradendritic recordings, as well as intrasomatic recordings from 27 granule cells, 4 stratum pyramidale interneurons, and 2 stratum radiatum interneurons. We did not find synaptic interactions between L-M interneurons and granule cells or stratum radiatum interncurons. Using hypcrpolarizing or subthreshold depolarizing intracellular current injection, we did not find any evidence of 
A
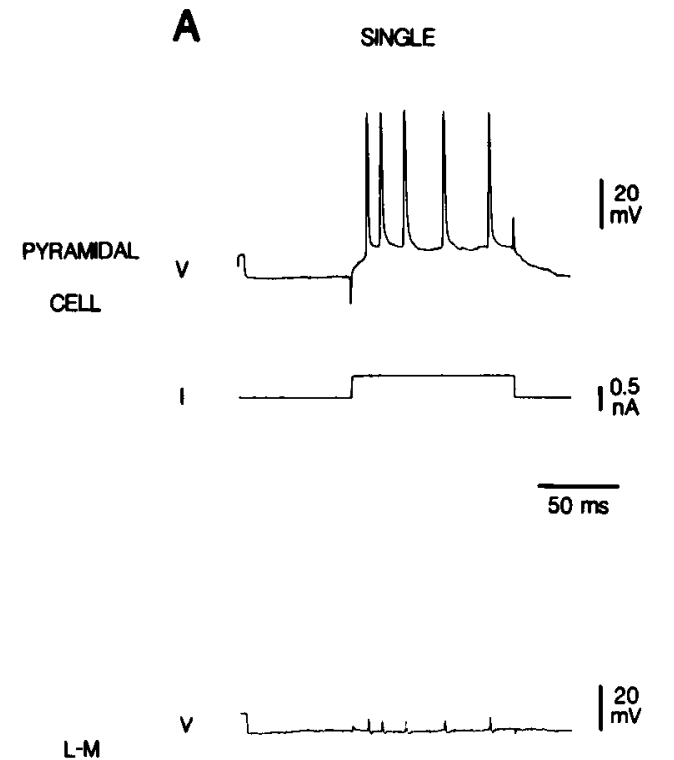

INTERNEUAON

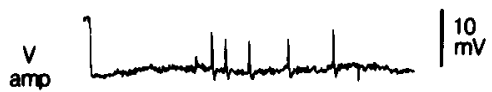

B

SINGLE

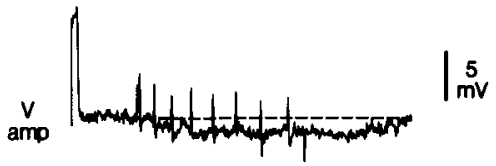

$\mid \begin{gathered}20 \\ \mathrm{mV}\end{gathered}$

$\vee \quad$

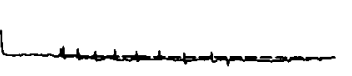

$50 \mathrm{~ms}$
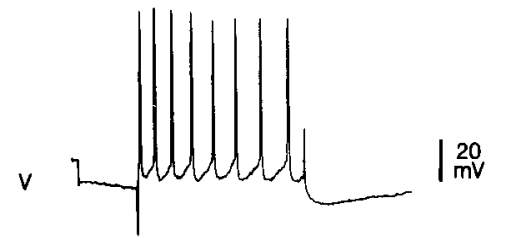

1

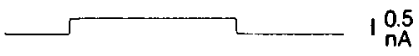

C

AVERAGE (25)

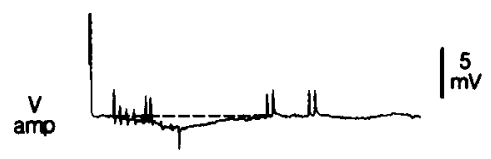

$\mid \begin{array}{ll}20 \\ \mathrm{mV}\end{array}$

$v$

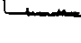

$\overline{100 \mathrm{~ms}}$

$\mid \begin{aligned} & 20 \\ & \mathrm{mV}\end{aligned}$

0.5
$\mathrm{nA}$

Figure 1. Hyperpolarization of CAl pyramidal cell by L-M interneuron. A, Lack of effect of pyramidal cell stimulation on L-M interneuron. A depolarizing current pulse ( $100 \mathrm{msec}, 0.5 \mathrm{nA}$ ) in the pyramidal cell evoked 5 action potentials (top 2 traces). There were no correlated changes in membrane potential of the interneuron (bottom 2 traces). The small spikelike events in L-M interneuron voltage trace are capacitative coupling artifacts. In this and subsequent figures, traces labeled $V_{\text {amp }}$ and $V$ differ only in amplification (see respective calibration). Also, in this and subsequent figures, a rectangular calibration pulse $(5 \mathrm{msec}, 10 \mathrm{mV}$ ) is present at the onset of each voltage trace. $B$, Intrasomatic depolarization (with $0.5 \mathrm{nA}$, $100 \mathrm{msec}$ current pulse) of L-M interneuron elicited 8 action potentials (bottom 2 traces). During this train of action potentials, the membrane potential of the CAl pyramidal cell hyperpolarized (top 2 traces). Broken line represents resting membrane potential. Following the offset of interneuron firing, the membrane potential gradually returned to resting level in approximately $50 \mathrm{msec}$. $C$, Average traces of 25 responses as in $B$. Note change in time base. Bottom 2 traces, Average response of L-M interneuron to depolarizing current pulse. Temporal dispersion of action potentials results in action potential amplitude variations in average voltage trace. During the train of L-M action potentials, a gradual hyperpolarization of the membrane developed in the CA1 pyramidal cell (top 2 traces). The average hyperpolarization gradually recovered to resting membrane potential (broken line) in about $120 \mathrm{msec}$. In the pyramidal cell average voltage trace, small spikelike events are capacitative coupling artifacts or (when no action potentials are present in the L-M interneuron) spontaneous action potentials in the pyramidal cell. Note occasional rebound action potentials in pyramidal cell following recovery from hyperpolarization. L-M interneuron $\mathrm{RMP},-59 \mathrm{mV} ; R_{\text {in }}, 50 \mathrm{M} \Omega$; action potential amplitude, $78 \mathrm{mV}$; pyramidal cell RMP, $-65 \mathrm{mV}$; action potential amplitude, $70 \mathrm{mV}$.

electrotonic coupling between L-M interneurons and pyramidal, nonpyramidal cells of CAl or dentate granule cells.

\section{L-M interneuron/intrasomatic CAI pyramidal cell pairs}

We have tested for synaptic interactions between $15 \mathrm{~L}-\mathrm{M}$ interneurons [mean $\pm \mathrm{S} / \mathrm{E}$; RMP, $-56 \pm 4.5 \mathrm{mV} ; R_{\text {in }}, 87 \pm 7.7 \mathrm{M} \Omega$; action potential (AP) amplitude, $66 \pm 3.0 \mathrm{mV}$ ] and $49 \mathrm{CAl}$ pyramidal cells recorded intrasomatically (RMP, $-60 \pm 0.9$ $\mathrm{mV}$; AP amplitude, $67.5 \pm 1.3 \mathrm{mV}$ ). Of these $15 \mathrm{~L}-\mathrm{M}$ interneurons, 9 were recorded in transverse slices and 6 in longitudinal slices. In the 49 pyramidal cell/L-M interneuron pairs tested, stimulation of the pyramidal cell, producing a burst of action potentials, did not result in any correlated changes in membrane potential in the L-M interneuron (aside from capacitative coupling artefacts). However, in 9 of the 42 pyramidal cell/L-M interneuron pairs (21\%) in which the L-M interneuron was depolarized to produce a train of action potentials, a hyperpolarization of the pyramidal cell membrane gradually developed during the train of action potentials in the L-M interneuron. We will refer to this hyperpolarization as an "IPSP" (inhibitory postsynaptic potential), even though identity of this response with the classically studied IPSP has still to be established. Following termination of the train, the pyramidal cell membrane potential gradually recovered to resting level. Of the

Table 1. Characteristics ( \pm SE) of IPSPs evoked by L-M interneuron stimulation

Postsynaptic cell

\begin{tabular}{|c|c|c|c|c|c|}
\hline Cell type & $n$ & Mean RMP (mV) & $\begin{array}{l}\text { Peak amplitude } \\
(\mathrm{mV})\end{array}$ & $\begin{array}{l}\text { Peak latency } \\
\text { (msec) }\end{array}$ & $\begin{array}{l}\text { Decay time } \\
(\mathrm{msec})\end{array}$ \\
\hline Pyramidal cell soma & $9 / 42$ & $-60 \pm 1.4$ & $0.91 \pm 0.26$ & $86 \pm 12.7$ & $93 \pm 11.0$ \\
\hline Pyramidal cell dendrite & $11 / 46$ & $-67 \pm 1.1$ & $0.67 \pm 0.12$ & $74 \pm 9.0$ & $76 \pm 9.3$ \\
\hline
\end{tabular}


A PHEOBASE NO LTM STMM.

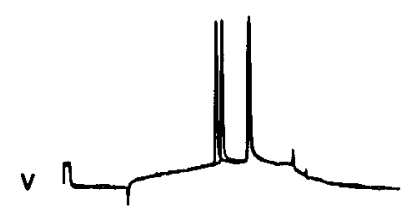

PYRAMDAL CELL
B

RHEOBASE WTH L-M STIM. v

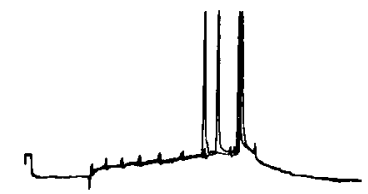

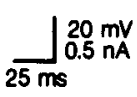

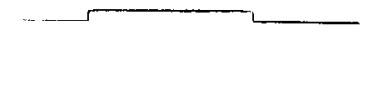

A

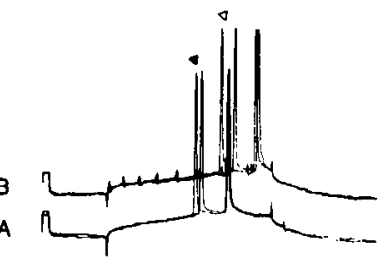

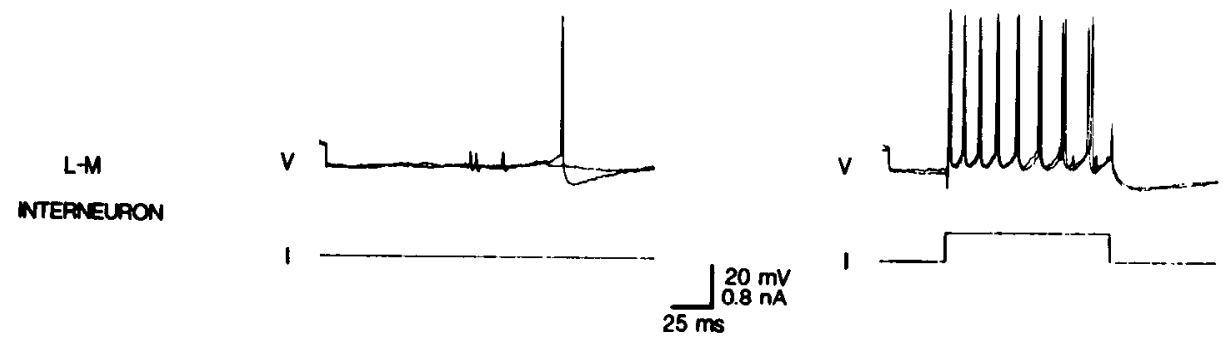

Figure 2. Delay of pyramidal cell action potentials at rheobase during stimulation of L-M interneuron. Same cell pair as Figure 1. A, Two CA1 pyramidal cell action potentials were evoked with rheobasic current injection (top 2 traces; each trace, 2 superimposed trials) without stimulation of L-M interneuron (bottom 2 traces). $B$, Action potentials in CA1 pyramidal cell were evoked (same rheobasic current injection as in $A$ ) with a delay (top 2 traces) during concurrent stimulation of L-M interneuron (bottom 2 traces). $C$, Superimposed voltage records of $A$ and $B$ showing delay (approximately $15 \mathrm{msec}$ ) in pyramidal cell evoked action potentials during L-M interneuron stimulation (open triangle, during L-M stimulation; closed triangle, without L-M stimulation).

9 synaptically coupled cell pairs, 6 were recorded in longitudinal and 3 in transverse slices. The average peak amplitude, latency, and decay of these IPSPs are indicated in the first line of Table 1. In these 9 pyramidal cells, the IPSPs evoked by stimulation of L-M interneurons had an average peak amplitude of 0.91 $\mathrm{mV}$. The IPSPs reached their maximum, on average, in $86 \mathrm{msec}$, and they recovered to resting membrane potential in an average of $93 \mathrm{msec}$.

Figure 1 illustrates a pyramidal cell/L-M interneuron pair in which the synaptic interactions found approximated the average response. Figure $1 A$ shows the absence of response in the L-M interneuron during stimulation of the pyramidal cell. The IPSP produced in the pyramidal cell during stimulation of the L-M interneuron is shown in Figure $1 B$. Figure $1 C$ illustrates the average of 25 single traces as in $1 B$. In this case, the average IPSP had a peak amplitude of $1.2 \mathrm{mV}$, a peak latency of 104 $\mathrm{msec}$, and a decay to baseline of $120 \mathrm{msec}$.

The inhibitory nature of the pyramidal cell hyperpolarizations produced during stimulation of L-M interneurons is shown in
Figure 2 (same cell pair as Fig. 1). The pyramidal cell responses ( 2 superimposed traces) to intrasomatic rheobasic current injection is shown in Figure $2 A$. The pyramidal cell responses to the same current injection but given concurrently with L-M stimulation (L-M stimulation producing pyramidal cell hyperpolarizations as in Fig. 1) are illustrated in Figure $2 B$. As shown in Figure $2 C$, the latency of the current-evoked action potentials is delayed when the L-M interneuron is stimulated concurrently (open triangle) compared with the unstimulated controls (filled triangle). For this cell pair, during L-M stimulation, the delay to the first action potential was $18 \mathrm{msec}$.

In one of the 9 synaptically coupled interneuron/intrasomatic pyramidal cell pairs, the L-M interneuron was filled with $L Y$. The morphology of this L-M interneuron is shown in Figure 3. Typical of L-M interneurons (Lacaille and Schwartzkroin, 1988), the soma was multipolar, approximately $25 \mu \mathrm{m}$ in diameter, and situated in stratum lacunosum-moleculare near the stratum radiatum border. Primary dendrites radiated from the soma and projected in stratum lacunosum-moleculare and stratum radia-

Figure 3. LY-filled L-M interneuron that, upon stimulation, hyperpolarized CAl pyramidal cell (see Fig. 4 for electrophysiological results). $A$ and $B$, Two adjacent sections containing LY-filled L-M interneuron. The soma $(A$ only) is located in stratum lacunosum-moleculare $(l m)$ near stratum radiatum border. Beaded dendritic processes branch and ramify profusely in strata lacunosum-moleculare and radiatum $(r)$. LY-filled axon originates from a dendrite (arrow in $A$ ). In the plane of focus of $A$ and $B$, LY-filled fine axonal processes are faintly seen in strata lacunosum-moleculare, radiatum, and pyramidale $(p)$. CAl pyramidal cell to which the interneuron was synaptically-coupled (see Fig. 4) was approximately situated in the area marked with an asterisk in $A$ and $B$. $C$, Higher-power fluorescence photomicrograph of area outlined by the $b o x$ in $A$, showing a section 


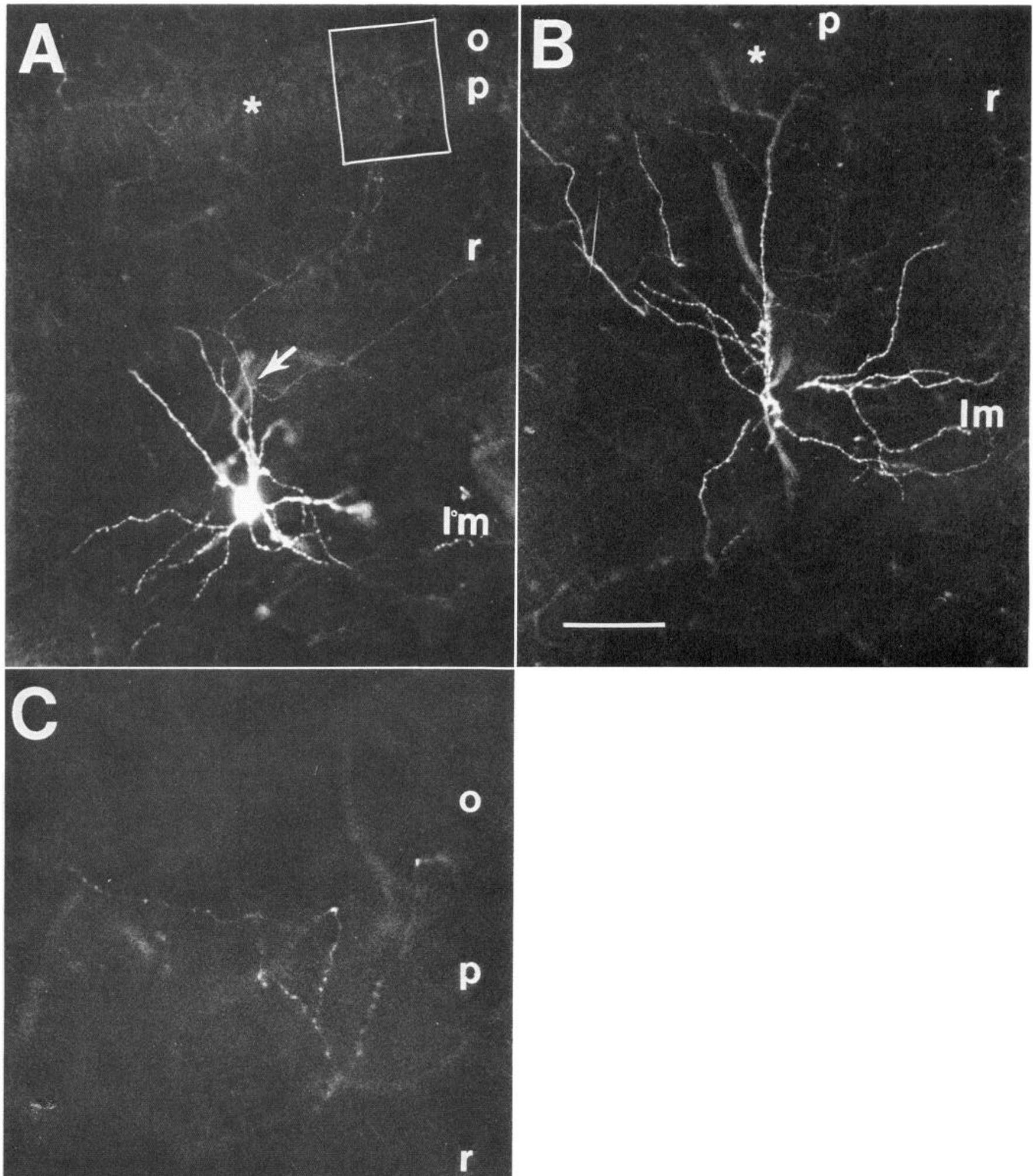

of varicose axon descending through stratum radiatum, entering stratum pyramidale, and further coursing in stratum oriens $(o)$. Calibration bar (in $B$ ): $A$ and $B, 100 \mu \mathrm{m} ; C, 40 \mu \mathrm{m}$. 
A

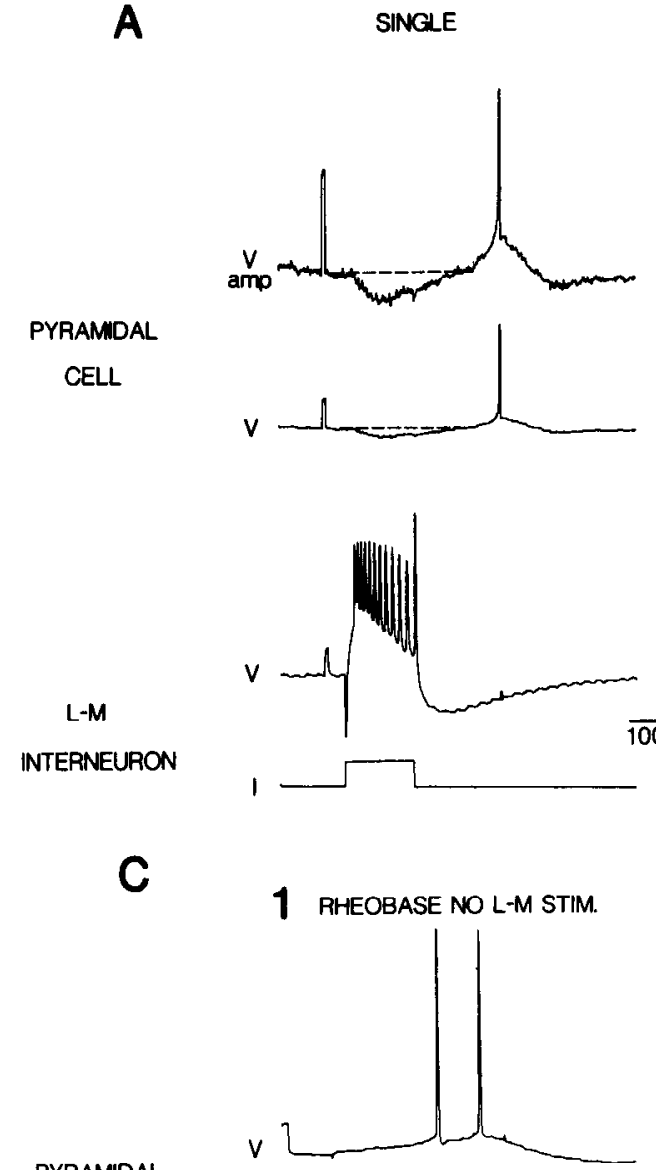

PYRAMIDAL

CELL

L-M

INTERNEURON

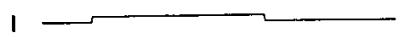

$\checkmark$

2 RHEOBASE WITH L-M STIM.

1

1

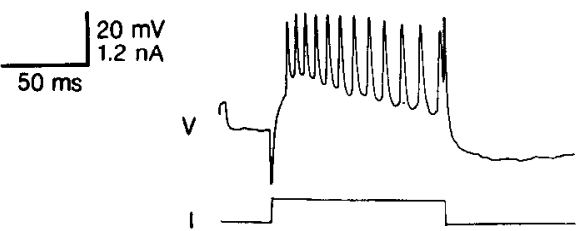

3

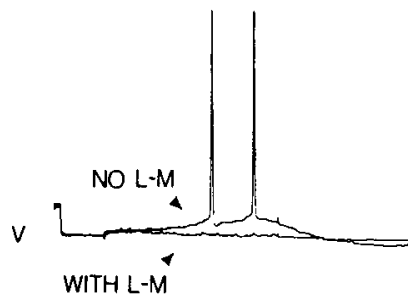

Figure 4. Inhibition of CAl pyramidal cell by LY-filled L-M interneuron shown in Figure 3 . Single trace $(A)$ and average of 15 traces $(B)$ of depolarizing current pulse $(0.5 \mathrm{nA}, 100 \mathrm{msec})$ producing 12 action potentials in L-M interneuron (bottom 2 traces); during the train of action potentials, an inhibitory postsynaptic potential (IPSP) gradually developed in the CA1 pyramidal cell (top 2 traces). Following the offset of the depolarizing pulse in the interneuron, the pyramidal cell membrane potential recovered to resting level (broken line) in approximately 50 msec (single trace in $A$ ) or $100 \mathrm{msec}$ (average trace in $B$ ). CAl pyramidal ccll action potentials are truncated in $A$. $C$, Rheobasic current injection cvoked 2 action potentials in the pyramidal cell $(C 1$ top 2 traces $)$. Stimulation of $\mathrm{L}-\mathrm{M}$ interneuron $(0.5 \mathrm{nA}, 100 \mathrm{msec})$ producing a train of action potentials $(C 2$, bottom 2 traces $)$, given concurrently with rheobasic stimulation of the pyramidal cell, blocked the production of action potentials in the pyramidal cell $(C 2$, top 2 traces). $C 3$, Superimposed traces of pyramidal cell responses to rheobasic current injection without (from $C 1)$ and during (from $C 2$ ) stimulation of L-M interneuron. L-M interneuron RMP, $-55 \mathrm{mV} ; R_{\text {in }}, 115 \mathrm{M} \Omega$, action potential amplitude, $43 \mathrm{mV}$; pyramidal cell RMP, $-61 \mathrm{mV}$; action potential amplitude, $80 \mathrm{mV}$.

tum. The LY-filled axon (Fig. 3A) emerged from a dendrite (arrow) and branched mostly in strata radiatum and pyramidale. In Figure $3 C$ the varicose axon is shown at higher power descending in stratum radiatum ( $\mathrm{r}$ ), crossing stratum pyramidale (p), and entering stratum oriens (o). The approximate location of the pyramidal cell to which this L-M interneuron was synaptically coupled is indicated by an asterisk in stratum pyramidale in Figure 3. (This location was obtained from the position of the recording electrodes during the electrophysiological experiments.) Stimulation of this L-M interneuron with an intra- cellular depolarizing current pulse elicited a train of action potentials (Fig. $4 A$ single trace; Fig. $4 B$ average of 15 traces). During the L-M interneuron train of action potentials, an IPSP gradually developed in the pyramidal cell (Fig. 4, $A, B$ ). Following the offset of firing in the L-M interneuron, the IPSP in the pyramidal cell gradually decayed to resting membrane potential. In the pyramidal cell, rebound excitation often occurred following the decay of the IPSP (see Fig. 4 $A$ ). The IPSP evoked by stimulation of the L-M interneuron was effective in blocking the production of action potentials elicited in the pyramidal cell with rheobasic 

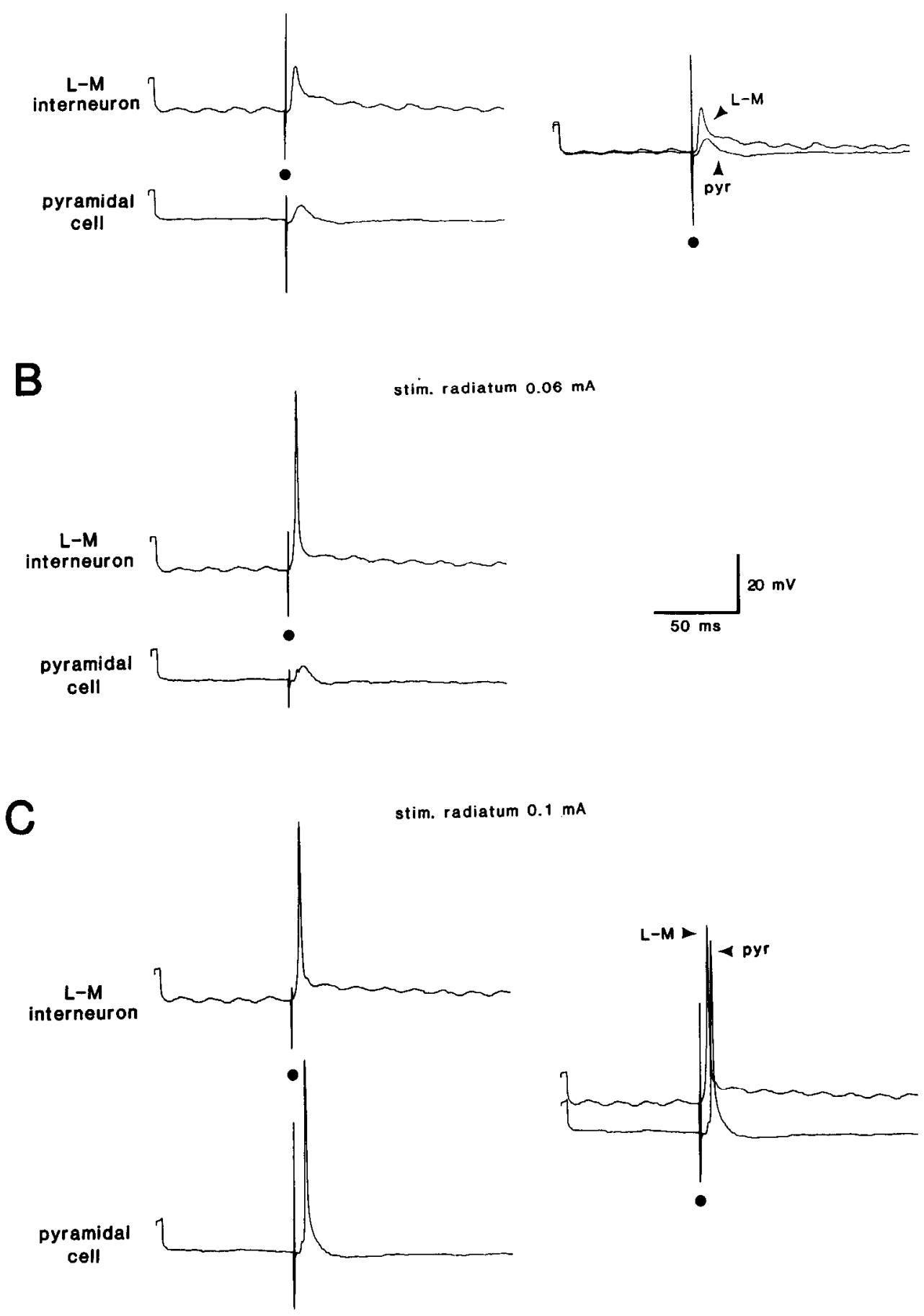

Figure 5. Feedforward excitation of $\mathrm{L}-\mathrm{M}$ interneurons. $A-C$, Simultaneous paired recordings from L-M interneuron (top traces) and CA1 pyramidal cell (bottom traces) during stimulation of stratum radiatum (filled circle, $0.05 \mathrm{msec}$ pulse duration) at resting membrane potential. $A$, Subthreshold synaptic responses following low-intensity stimulation $(0.05 \mathrm{~mA})$. At right, these synaptic responses are superimposed. Note greater efficacy of synaptic response in L-M interneuron reflected in a greater rate of rise and greater amplitude of EPSP than in the pyramidal cell. $B$, Slightly more intense stimulation of stratum radiatum $(0.06 \mathrm{~mA})$ evoked an EPSP suprathreshold in L-M interneuron but still subthreshold in CAl pyramidal cell. $C$, More intense stratum radiatum stimulation $(0.1 \mathrm{~mA})$ was necessary for CA1 pyramidal cell EPSP to reach threshold and trigger an action potential. However, as shown at right, with same traces nearly superimposed, the action potential evoked synaptically in the L-M interneuron preceded the action potential elicited in the pyramidal cell (in this instance, $2.2 \mathrm{msec}$ time difference peak to peak). In L-M interneuron recordings, grounding problems resulted in a higher level of electrical interference. L-M interneuron RMP, $-51 \mathrm{mV} ; R_{\text {in }}, 66 \mathrm{M} \Omega$; action potential amplitude, $69 \mathrm{mV}$; pyramidal cell RMP, $-59 \mathrm{mV}$; action potential amplitude 64 $\mathrm{mV}$.

current injection (Fig. $4 C$ ). As in other cell pairs, stimulation of the pyramidal cell did not cause any membrane shift in the L-M interneuron (data not shown).

In some L-M interneuron/intrasomatic pyramidal cell pairs (in transverse slices), we examined the synaptic responses evoked in both interneuron and pyramidal cell by electrical stimulation of major afferents. Figure 5 shows that L-M interneurons were synaptically activaled in a feedforward manner with respect to pyramidal cells. Low-intensity stimulation (Fig. $5 A$ ) subthresh- old for both cells evoked a larger and a faster rising EPSP in the interneuron than in the pyramidal cell. Increasing stimulation intensity resulted in an EPSP of sufficient amplitude in the L-M interneuron to elicit an action potential, whereas the EPSP in the pyramidal cell was still of subthreshold amplitude (Fig. 5B). With sufficient stimulation, the EPSPs in both cells reached threshold (Fig. 5C); however, the L-M interneuron action potential was evoked at a shorter latency than the pyramidal cell action potential (2.2 msec earlier for responses of Fig. 5C). 

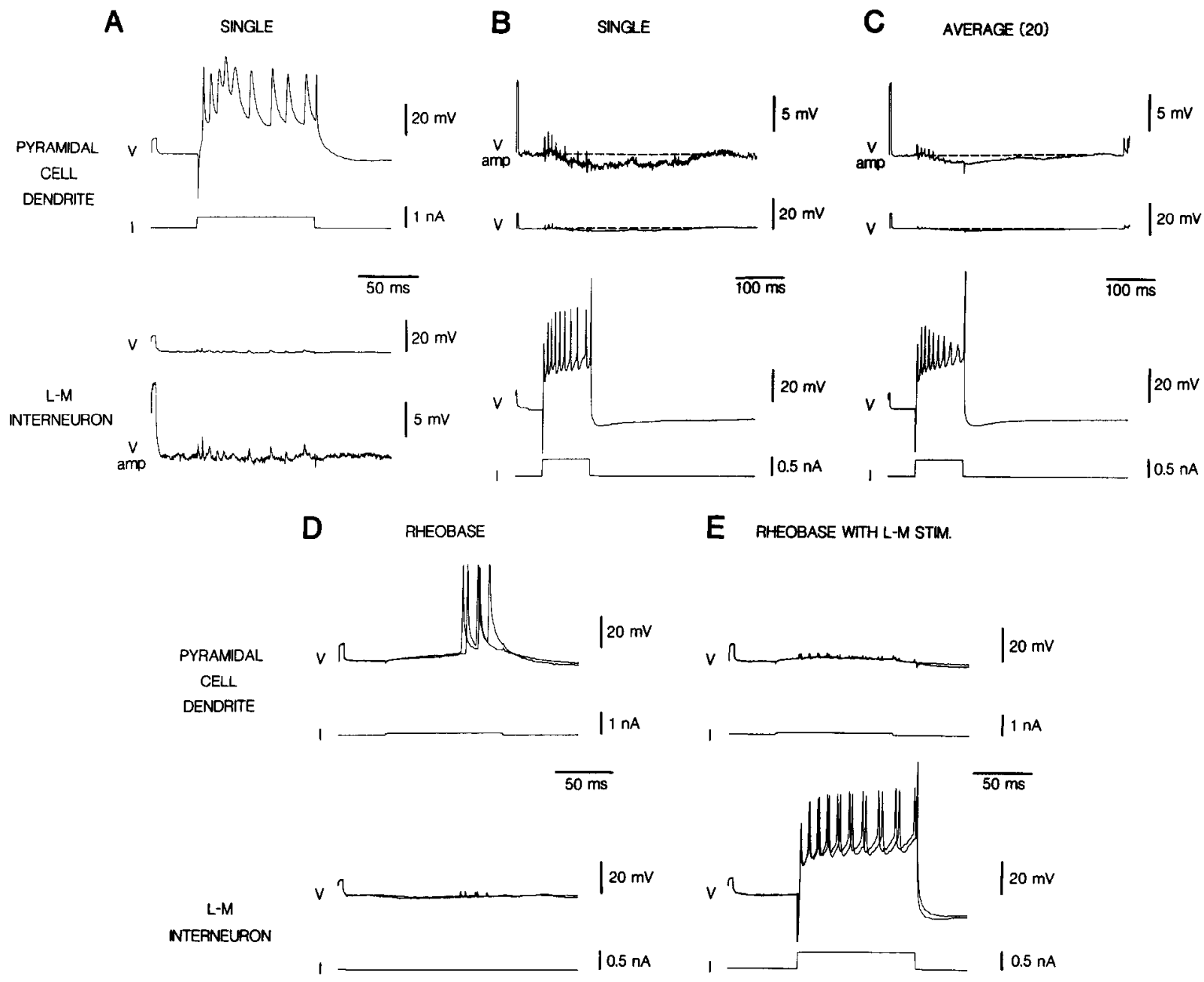

Figure 6. Hyperpolarization of intradendritically recorded pyramidal cell membrane potential by stimulation of L-M interneuron. A, Intradendritic depolarizing current pulse $(0.5 \mathrm{nA}, 100 \mathrm{msec})$ evoked a burst of spikes of varying amplitude and duration in the pyramidal cell intradendritic recording (top 2 traces). There were no correlated voltage changes in the intrasomatic recording from the L-M interneuron during this bursting activity (bottom 2 traces). Small fluctuations are capacitative coupling artifacts. $B$ and $C$, Single trace $(B)$ and average of 20 traces $(C)$. Depolarizing current pulse $(0.5 \mathrm{nA}, 100 \mathrm{msec})$ in the interneuron evoked a train of action potentials (bottom 2 traces). During the L-M interneuron action potential train, an IPSP was gradually produced in the pyramidal cell intradendritic recording (top 2 traces). After the offset of L-M stimulation, the IPSP gradually recovered to resting membrane potential (broken line). $D$, Rheobasic current injection in pyramidal intradendritic recording evoked 2 action potentials ( 2 superimposed traces, top 2 records). E. Same intracellular current injection failed to evoke any action potentials in the pyramidal cell (top 2 traces) when L-M interneuron is stimulated $(0.5 \mathrm{nA}, 100 \mathrm{msec})$ concurrently (bottom 2 traces). L-M interneuron RMP, $-62 \mathrm{mV} ; R_{\mathrm{in}}, 91 \mathrm{M} \Omega$; action potential amplitude, $57 \mathrm{mV}$; pyramidal cell dendrite $\mathrm{RMP},-70 \mathrm{mV} ; K_{\mathrm{in}}, 60 \mathrm{M} \Omega$; action potential amplitude, $60 \mathrm{mV}$.

\section{$L-M$ interneuron/intradendritic pyramidal cell pairs}

We have tested for possible interactions between $13 \mathrm{~L}-\mathrm{M}$ interneurons (mean \pm SEM; RMP, $-61 \pm 1.0 \mathrm{mV} ; R_{\text {in }}, 67 \pm 15$ M ; AP amplitude, $68 \pm 2.4 \mathrm{mV}$ ) and 46 intradendritically recorded pyramidal cells $\left(\mathrm{RMP},-67 \pm 0.8 \mathrm{mV} ; R_{\text {in }}, 50 \pm 2.0\right.$ $\mathrm{M} \Omega$; AP amplitude, $62 \pm 1.1 \mathrm{mV}$ ). These recordings were obtained in 12 longitudinal slices (38 pairs) and 1 transverse slice (8 pairs). In the $46 \mathrm{~L}-\mathrm{M}$ interneuron/intradendritic pyramidal cell pairs tested, intracellular stimulation evoking a burst of spikes in the pyramidal cell dendrite was never associated with any correlated changes in membrane potential in the L-M interneuron. In 11 of the $43 \mathrm{~L}-\mathrm{M}$ interneuron/pyramidal cell dendrite pairs tested (26\%), stimulation of the L-M interneuron produced a hyperpolarization of the pyramidal cell membrane. As shown on line 2 of Table 1, for the IPSPs of these 11 cell pairs at resting membrane potential, the average peak amplitude was $0.67 \mathrm{mV}$; latency to peak, $74 \mathrm{msec}$, and time to decay, 76 $\mathrm{mV}$.

Records of a synaptically coupled L-M interneuron/pyramidal cell dendrite pair are shown in Figure 6. Depolarizationinduced firing of the pyramidal cell dendrite did not produce correlated changes in membrane potential of the L-M interneuron (Fig. $6 \mathrm{~A}$; small fluctuations in L-M interneuron are capacitative coupling artifacts). However, the pyramidal cell dendritic membrane potential gradually hyperpolarized during the current-induced train of action potentials in the L-M interneuron (Fig. $6 \mathrm{~B}$, single trace; Fig. $6 \mathrm{C}$, average of 20 traces). Following the offset of the L-M interneuron train of action potentials, the pyramidal cell dendritic membrane potential gradually returned to resting level. The IPSP produced in the pyramidal cell dendrite by stimulation of L-M interneuron was sufficient to block the action potentials evoked by rheobasic current injection when the 2 stimuli were given concurrently (Fig. 6, D,E). 
1

L-M NTERNEUAON

A

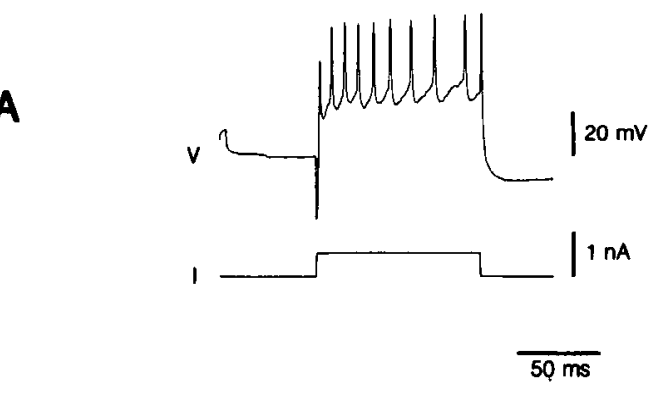

2

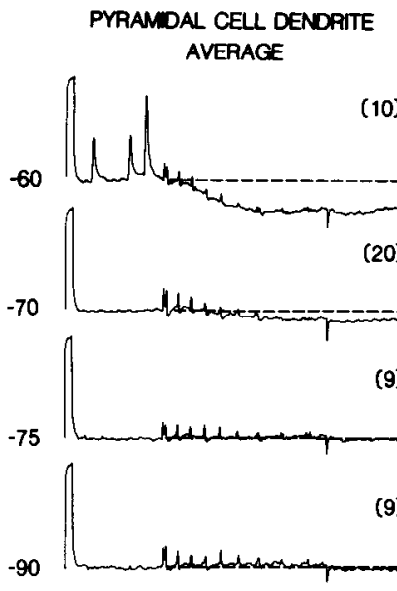

3

(10)

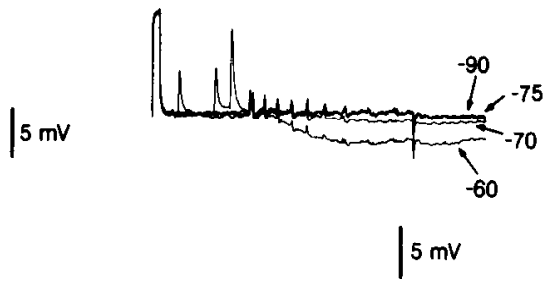

$50 \mathrm{~ms}$

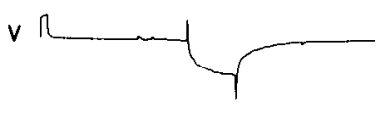

1

I InA

B

I

I I nA

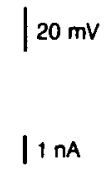

1

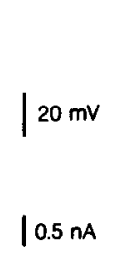

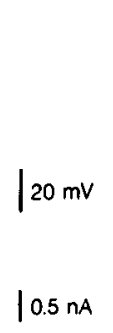

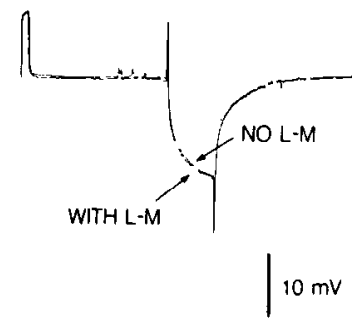

Figure 7. Relation of pyramidal cell intradendritic IPSP amplitude to membrane potential and lack of membrane resistance change during IPSP. Same cell pair as Figure 6: $A 1$, Stimulation of L-M interneuron with a depolarizing current pulse $(0.5 \mathrm{nA}, 100 \mathrm{msec})$ evoked a train of action potentials (as in Fig. 6). A2, Average of pyramidal cell intradendritic recordings (number of traces indicated in parentheses) at different membrane potentials during stimulation of L-M interneuron (same as in $A I$ ). At resting membrane potential (second trace; $-70 \mathrm{mV}$ ), a small IPSP was produced in the pyramidal cell dendrite during L-M interneuron stimulation. During tonic depolarization of the pyramidal cell membrane to - 60 $\mathrm{mV}$ (top trace), an IPSP of greater amplitude was produced in the pyramidal cell dendrite. With tonic hyperpolarization of the pyramidal cell membrane to $-75 \mathrm{mV}$ (third trace), no voltage change was associated with the interneuron stimulation. Hyperpolarization of the membrane to $-90 \mathrm{mV}$ (bottom trace) failed to produce a reversal of the IPSP. A3, Superimposed average traces of $A 2$. B1, Average (top 2 traces) of 10 input resistance measurements of pyramidal cell dendrite with hyperpolarizing current pulses $(0.3 \mathrm{nA}, 40 \mathrm{msec})$ without concurrent stimulation of L-M interneuron (bottom 2 traces). B2, Average of pyramidal cell dendrite input resistance (top 2 traces) during the IPSP produced by L-M stimulation (bottom 2 traces; $0.5 \mathrm{nA}, 100 \mathrm{msec}$; as in $A$ ). B3, Superimposed average input resistance without (from $B 1$ ) and during (from $B 2$ ) L-M stimulation, showing no differences in voltage responses to hyperpolarizing current pulses.

The IPSPs evoked in pyramidal cell dendrites by L-M stimulation were sensitive to manipulations of membrane potential. Figure $7 A$ shows, for the same L-M interneuron/pyramidal cell dendrite pair as in Figure 6, that the IPSP amplitude increases with depolarization of the pyramidal cell dendritic membrane and decreases with hyperpolarization. For this cell pair, the peak amplitude of the average IPSP was $2.7 \mathrm{mV}$ at $-60 \mathrm{mV}, 1.4 \mathrm{mV}$ at $-70 \mathrm{mV}$ (resting membrane potential). The IPSP was abolished at -75 and $-90 \mathrm{mV}$, but IPSP reversal was not observed. The IPSPs recorded in 5 other cell pairs displayed a similar voltage dependency. In 3 cell pairs the IPSP was abolished at a mean membrane potential of $-74.3 \mathrm{mV}$ (SD $4.0 \mathrm{mV}$ ).

In 5 synaptically coupled L-M interneuron/pyramidal cell dendrite pairs, a hyperpolarizing current pulse was given during the IPSP to measure the pyramidal cell input resistance $\left(R_{\mathrm{in}}\right)$.
In 5 of 5 pairs, the input resistance of the membrane did not appear to change during the IPSP (e.g., see Fig. $7 B$ ).

\section{$L-M$ interneuron/CAI interneuron pairs}

In the course of our paired recording experiments on pyramidal cells, we have obtained simultaneous recordings between L-M interneurons and 4 stratum pyramidale interneurons (mean \pm $\mathrm{SE}$; RMP, $-56 \pm 5.3 \mathrm{mV}$; AP amplitude, $56 \pm 2.8 \mathrm{mV}$ ). In 4 of $4 \mathrm{~L}-\mathrm{M}$ interneuron/stratum pyramidale interneuron pairs, stimulation of stratum pyramidale interneurons did not produce any change in L-M interneuron membrane potential. However, in 2 of 4 pairs, stimulation of the L-M interneuron produced a hyperpolarization of the stratum pyramidale interneuron membrane. As shown on line 3 of Table 1, these stratum pyramidale interneuron IPSPs had a mean peak amplitude of $0.74 \mathrm{mV}$, 
A

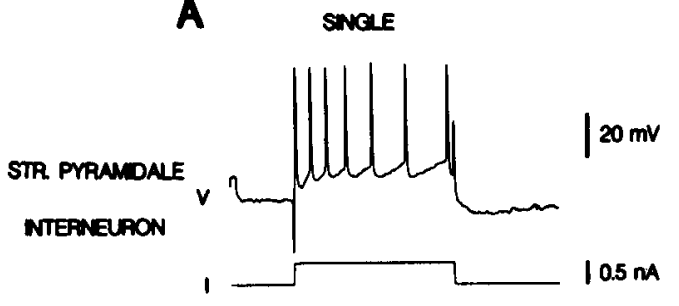

V

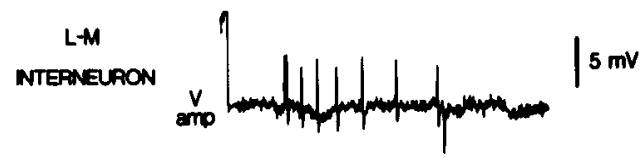

D

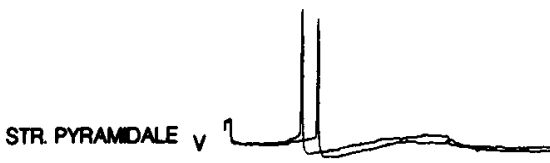

NTEPNELAON

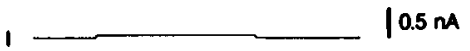

B
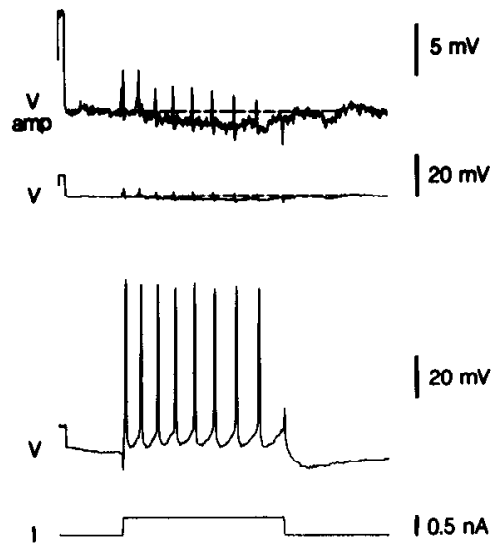

E

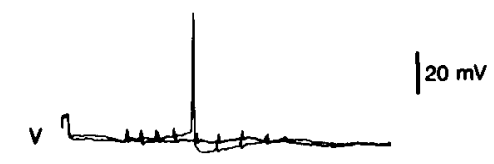

$\mid 0.5 \mathrm{nA}$

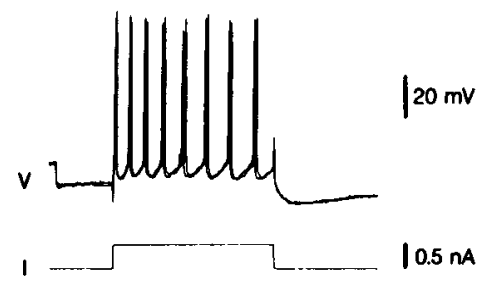

C

AVERACE (25)

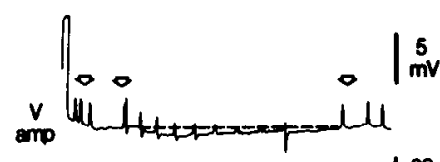

$\left.\right|_{\mathrm{mV}} ^{20}$
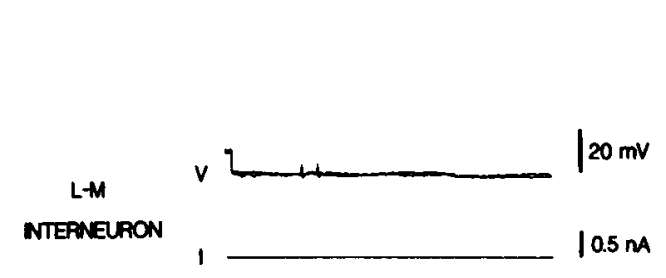

Figure 8. Inhibition of stratum pyramidale interneuron by L-M interneuron. $A$, Stimulation $(0.5 \mathrm{nA}, 100 \mathrm{msec})$ of stratum pyramidale interneuron (top 2 traces) did not produce any correlated changes in membrane potential in L-M interneuron (bottom 2 traces). $B$ and $C$, Single trace $(B)$ and average of 25 traces $(C)$, depolarizing current injection $(0.5 \mathrm{nA}, 100 \mathrm{msec})$ in L-M interneuron elicited a train of 8 action potentials (bottom 2 traces). Temporal dispersion of action potentials in individual traces results in variation in amplitude and duration of action potentials in average trace (in $C$ ). During the train of action potentials in the L-M interneuron, the stratum pyramidale interneuron membrane potential gradually hyperpolarized (top 2 traces). Following offset of stimulation, the IPSP rapidly (approx. $25 \mathrm{msec}$ ) recovered to resting membrane potential (broken line). Note in average voltage trace of $C$ (top trace, $V_{\mathrm{amp}}$ ) spontaneous action potentials (of reduced amplitude because of averaging) were seen in stratum pyramidale interneuron before the onset of L-M interneuron stimulation and after recovery of IPSP to resting membrane potential. There were no spontaneous action potentials during the IPSP, suggesting the efficacy of the IPSP in preventing action potential production (small spikelike fluctuations during L-M stimulation are capacitative coupling artifacts). $D-F$, Delay and inhibition of stratum pyramidale interneuron action potentials by stimulation of L-M interneuron (each trace is 2 superimposed records). $D$, Rheobasic stimulation ( $0.05 \mathrm{nA}, 100 \mathrm{msec})$ of stratum pyramidale interneuron evoked a single action potential (top 2 traces). Note the pronounced afterhyperpolarization following the action potential, characteristic of these interneurons. $E$, Same intensity stimulation of stratum pyramidale interneuron (top 2 traces) but during stimulation ( $0.5 \mathrm{nA}$, $100 \mathrm{msec}$ ) of L-M interneuron (bottom 2 traces). In the 2 superimposed traces, the stratum pyramidale interneuron action potential is either delayed or prevented. $F$, Stratum pyramidale interneuron voltage traces of $D$ (no L-M stimulation) and $E$ (with L-M stimulation), showing the delay and inhibition of the current evoked action potential during L-M interneuron stimulation. L-M interneuron RMP, $-59 \mathrm{mV} ; R_{\text {in }}, 50 \mathrm{M} \Omega$; action potential amplitude, $78 \mathrm{mV}$; stratum pyramidale interneuron $\mathrm{RMP},-60 \mathrm{mV}$; action potential amplitude, $60 \mathrm{mV}$.

peak latency of $58 \mathrm{msec}$, and decay time of $70 \mathrm{msec}$. The synaptic interactions of such an L-M interneuron/stratum pyramidale interneuron pair are illustrated in Figure 8. The L-M interneuron membrane potential was unaffected during stimulation-induced firing of stratum pyramidale interneurons (Fig. 8A). Stimulation of the L-M interneuron with a depolarizing current pulse produces a train of action potentials in the L-M interneuron and an IPSP in the stratum pyramidale interneuron (Fig. $8 B$, single trace; Fig. $8 C$, average of 25 traces). As shown in Figure $8, D-F$, the IPSP evoked in the stratum py- ramidale interneuron during the L-M interneuron action potential train is sufficient, when given concurrently, to delay and block the stratum pyramidale interneuron action potential normally evoked with rheobasic current injection.

\section{Discussion}

Using simultaneous intracellular recordings, we have examined the local circuit synaptic interactions between L-M interneurons and CAl cells. We have found that $L-M$ interneurons make inhibitory synaptic connections with pyramidal and nonpyra- 
midal cells of $\mathrm{CAl}$ region. We have not found any evidence of excitatory synaptic connections from CA1 pyramidal cells onto L-M interneurons. Neither have we observed any evidence of excitatory connections from L-M interneurons to pyramidal cells (i.e., "excitatory interneurons," see also Lacaille et al., 1987, and Knowles and Schwartzkroin, 1981a).

Small-amplitude membrane hyperpolarizations (approximately $1 \mathrm{mV}$ ) were recorded in pyramidal cells at resting membrane potential when L-M interneurons were made to fire a train of action potentials. These pyramidal cell responses were recorded intrasomatically in stratum pyramidale or intradendritically in stratum radiatum ( $1 / 2$ to $3 / 4$ of the distance toward stratum lacunosum-moleculare). Since we did not find any evidence of electrotonic coupling between L-M interneurons and pyramidal cells, these membrane hyperpolarizations are probably of synaptic origin [inhibitory postsynaptic potentials (IPSPs)]. These synaptically evoked hyperpolarizations were inhibitory in nature since they could delay and block pyramidal cell action potentials normally evoked with rheobasic current injections.

Both intrasomatically and intradendritically recorded pyramidal cell IPSPs displayed similar characteristics. IPSPs were not evident in pyramidal cells when L-M interneurons (presynaptic cell) were made to fire a single action potential. However, when a train of action potentials was elicited in the $\mathrm{L}-\mathrm{M}$ interneuron ( $100 \mathrm{msec}, 0.5 \mathrm{nA}$ depolarizing current pulse), an IPSP was evoked in the pyramidal cell. The IPSP had a slow, gradual build-up during the presynaptic train of action potentials. The intrasomatic IPSP reached its peak amplitude in 86 msec (mean for 9 cells) and the intradendritic IPSP in $74 \mathrm{msec}$ (mean of 11 cells). Following the offset of presynaptic stimulation, the IPSPs decayed slowly to resting membrane potential (intrasomatic IPSP time to decay 93 vs. $96 \mathrm{msec}$ for intradendritic IPSP). Although the intradendritic IPSP had a smaller mean peak amplitude than the intrasomatic IPSP $(0.7$ vs. 0.9 $\mathrm{mV})$, the difference may be due to the more negative intradendritic membrane potential ( $-67 \mathrm{mV}$ intradendritic vs. $-60 \mathrm{mV}$ intrasomatic). As shown with intradendritic pyramidal cell recordings, pyramidal cell IPSPs evoked during L-M stimulation are sensitive to intracellular membrane potential. IPSP amplitude increases with membrane depolarization and decreases with membrane hyperpolarization. In 3 cells, the IPSP was abolished at a mean membrane potential of $-74 \mathrm{mV}$. Further hyperpolarization of the membrane did not result in reversal of the IPSP. Finally, we could not measure any change in membrane input resistance during these IPSPs (as measured with hyperpolarizing current pulscs).

A number of the IPSP properties summarized above-no IPSP correlated with single "presynaptic" action potentials, slow build-up during the presynaptic train-might suggest a polysynaptic pathway between the L-M interneuron and the pyramidal cell. Although we cannot rule out this possibility, it seems unlikely that polysynaptic pathways are importantly involved since (1) electron microscopic investigations of intracellularlylabelled L-M interneurons show that they make monosynaptic symmetric contacts with pyramidal cells (unpublished observations); (2) L-M contacts with other interneurons, which inhibit pyramidal cells monosynaptically, are inhibitory (see Fig. 8; L-M symmetric contacts onto interneurons are also seen in EM); inhibition of inhibition would yield a net excitation, which was not seen in L-M interneuron-pyramidal pairs; and (3) many of the properties of the L-M interneuron to pyramidal cell IPSP are similar to IPSPs evoked by other interneuron types known to make monosynaptic contact with CA1 pyramidal cells.

For example, the characteristics of CAl pyramidal cell IPSPs evoked by L-M interneuron stimulation are similar to those of pyramidal cell IPSPs evoked by stimulation of basket cells (Knowles and Schwartzkroin, 1981a) or O/A interneurons (Lacaille et al., 1987). All 3 types of IPSPs have a slow, gradual onset. However, basket cell- and O/A interneuron-induced IPSPs decay more rapidly $(25-40 \mathrm{msec})$ than L-M interneuron-induced IPSPs (40-150 msec; mean, $90 \mathrm{msec}$ ). The slow kinetics of CA1 pyramidal cell IPSPs evoked by interneuron stimulation are in contrast to CA3 pyramidal cell unitary IPSPs, which have a more rapid rise time $(3-5 \mathrm{msec})$ and decay $(15-40 \mathrm{msec})$ (MacVicar and Dudek, 1980; Miles and Wong, 1984).

Another characteristic of L-M interneurons also shared with basket cells and $\mathrm{O} / \mathrm{A}$ interneurons is feedforward synaptic activation of interneurons with respect to C.A1 pyramidal cells (Knowles and Schwartzkroin, 1981a; Lacaille et al., 1987). In simultaneous intracellular recordings from interneurons and pyramidal cells, synaptic responses evoked from major hippocampal afferents (e.g., Fig. 5, radiatum stimulation) have greater efficacy in interneurons than in pyramidal cells and result in activation of action potentials in interneurons prior to, or in the absence of, production of action potentials in CAl pyramidal cells. Although it might be argued that the greater sensitivity of the interneuron is due to its slightly more positive resting potential (i.e., closer to action potential threshold), such an explanation does not account for (1) the shorter latency to PSP onset in interneurons compared with pyramidal cells; (2) the faster rate of rise; or (3) the appearance of synaptic events at lower stimulus intensitics. Whatever the mechanism, intcrncurons are extremely sensitive to afferent inputs and that sensitivity has potential functional consequences. Like basket cells and $\mathrm{O} / \mathrm{A}$ interneurons, L-M interneurons appear to be particularly well suited for mediating feedforward inhibition of pyramidal cells.

We have not found any evidence of synaptic connections from pyramidal cells to L-M interneurons. Anatomical evidence is consistent with the absence of physiologically induced synaptic connections from pyramidal cells to L-M interneurons since pyramidal cell axons primarily ascend in stratum oriens and project in the alveus (Ramon y Cajal, 1911; Lorente de No, 1934). Local axon collaterals of pyramidal cells have been reported; however, these collaterals are mostly confined to strata oriens and pyramidale (Lorente de No, 1934; Finch and Babb, 1981; Knowles and Schwartzkroin, 1981b). Although L-M interneurons sometimes have dendrites that reach into stratum oriens, the majority of their dendritic tree is in strata radiatum and lacunosum-moleculare (e.g., see Fig. 3; Lacaille and Schwartzkroin, 1988), which are mostly devoid of pyramidal cell axon collaterals. The absence of any pyramidal cell to L-M interneuron synaptic connections is in contrast to the EPSPs found in basket cells (Knowles and Schwartzkroin, 1981a) and $\mathrm{O} / \mathrm{A}$ interneurons (Lacaille et al., 1987) upon stimulation of CA1 pyramidal cells. Although negative results are difficult to interpret, especially in paired intracellular recording experiments, these results are supported by the anatomical evidence and the fact that the same experimental techniques (used by the same experimenters) have yielded positive results in the cases of basket cells and O/A interneurons (Knowles and Schwartzkroin, 1981a; Lacaille et al., 1987). The lack of excitatory connections from pyramidal cells to L-M interneurons further suggests that L-M interneurons, unlike basket cells and $\mathrm{O} / \mathrm{A}$ 
interneurons, do not mediate feedback inhibition onto pyramidal cells.

CAl pyramidal cells display a 2-component IPSP in response to orthodromic stimulation: (1) an early IPSP mediated by $\mathrm{Cl}^{-}$ ions and thought to involve recurrent (feedback) as well as feedforward inhibitory interneurons releasing GABA at synapses located mainly on pyramidal somata and activating $\mathrm{GABA}_{\mathrm{A}}$ receptors (Kandel ct al., 1961; Andersen ct al., 1964a, b; Newberry and Nicoll, 1985); and (2) a late IPSP mediated possibly by $\mathrm{K}^{+}$ions and involving feedforward inhibitory interneurons making synapses on pyramidal cell dendrites and releasing GABA, which acts on $\mathrm{GABA}_{\mathrm{B}}$ receptors (Alger and Nicoll, 1982a, b; Newberry and Nicoll, 1985). Many aspects of the L-M interneuron-evoked pyramidal cell IPSPs suggest that these interneurons may mediate the late IPSP of CA1 pyramidal cells. First, L-M interneuron-evoked IPSPs have slow kinetics (slow, gradual onset; long decay time) similar to the late IPSP (Alger, 1984; Knowles et al., 1984). Second, the type of voltage sensitivity (increase amplitude with depolarization within -55 to $-75 \mathrm{mV}$ range), apparent equilibrium potential $(-74 \mathrm{mV}$ with intradendritic recording for 3 cells), and lack of reversal at more negative membrane potentials of L-M interneuron-evoked IPSPs, are also consistent with a $\mathrm{K}^{+}$-mediated, late IPSP (Alger, 1984; Newberry and Nicoll, 1985). Finally, the L-M interneuron can be activated in a feedforward manner with respect to pyramidal cells but apparently not in a feedback (recurrent) manner. A direct test of this hypothesis would be to examine the sensitivity of the L-M interneuron-evoked IPSPs in pyramidal cells to $\mathrm{GABA}_{\mathrm{B}}$ receptor antagonist. It should be noted that interneurons similarly located in stratum lacunosum-moleculare are immunoreactive for glutamic acid decarboxylase (GAD; the synthesizing enzyme for GABA; Somogyi et al., 1984; Kunkel et al., 1986) and for GABA (Gamrani et al., 1986) and, thus, may use GABA as neurotransmitter. The L-M interneurons we have recorded from have similar cellular morphology (Lacaille and Schwartzkroin, 1988) and may be part of this GABAergic cell population. If our L-M interneurons are indeed the GABAergic cells that mediate the late component of the IPSP, then our intradendritically recorded pyramidal cell IPSP may represent GABAergic hyperpolarizing synaptic responses in pyramidal cell dendrites. Such a dendritic action of GABA would support the view that hyperpolarizing responses to GABA of hippocampal dendrites represent activation of specific synaptic receptors, whereas the depolarizing responses to GABA of dendrites represent activation of extrasynaptic receptors (Alger and Nicoll, 1982b).

We have also observed, in 2 of the $4 \mathrm{~L}-\mathrm{M}$ interneuron/stratum pyramidale interneuron pairs, small-amplitude IPSPs in stratum pyramidale interneurons during stimulation of L-M interneurons. These IPSPs were of comparable amplitude to those recorded in pyramidal cell somata $(0.7 \mathrm{vs} .0 .9 \mathrm{mV}$, respectively). However, their peak amplitude appeared to be reached more rapidly ( 58 vs. $86 \mathrm{msec}$ ), and their decay was also more rapid (70 vs. $93 \mathrm{msec}$ ). In these limited recordings we have not found any interactions from stratum pyramidale interneurons onto L-M interneurons. These results are similar to those found with $\mathrm{O} / \mathrm{A}$ and stratum pyramidale interneurons (in which case inhibition of stratum pyramidale interneuron by an $\mathrm{O} / \mathrm{A}$ interneuron was observed; Lacaille et al., 1987), and they suggest that L-M interneurons not only mediate inhibition of pyramidal cells but also inhibition of other nonpyramidal cells (presumably inhibitory interneurons).

\section{Intrinsic hippocampal circuitry}

The local circuitry of hippocampal CAl region and upper blade of dentate gyrus, as deduced from our studies on physiologically identified interneurons (Schwartzkroin and Mathers, 1978; Knowles and Schwartzkroin, $1981 \mathrm{la}$; Schwartzkroin and Kunkel, 1985; Kunkel et al., 1987; Lacaille et al., 1987; Lacaille and Schwartzkroin, 1988; prescnt paper) is illustrated in the diagrams of Figure 9. A pyramidal cell (P), a pyramidal basket cell (B), an oriens/alveus (O/A) interneuron, a lacunosum-moleculare $(\mathrm{L} / \mathrm{M})$ interneuron, and a granule cell $(\mathrm{G})$ are represented. Physiologically identified synaptic connections (open terminal = excitatory; closed terminal = inhibitory), as well as morphologically identified but as yet physiologically undefined (striped terminal) synaptic connections are illustrated. Afferent fibers in stratum radiatum $(R)$ make excitatory synaptic connections with pyramidal cell (synapse a), basket cell (synapse f), $\mathrm{O} / \mathrm{A}$ interneuron (synapse $\mathrm{g}$ ), and $\mathrm{L} / \mathrm{M}$ interneuron (synapse $\mathrm{l}$ ). Afferent fibers in stratum oriens $(O)$ make excitatory synaptic connections on pyramidal cell (synapse n), basket cell (synapse o), $\mathrm{O} / \mathrm{A}$ interneuron (synapse $\mathrm{m}$ ), and $\mathrm{L} / \mathrm{M}$ interneuron (synapse p). The greater efficacy of these excitatory synapses onto interneurons results in feedforward activation of basket cell, O/A interneuron and $\mathrm{L} / \mathrm{M}$ interneuron with respect to pyramidal cell activation. Axons in the alveus (A) make excitatory synaptic connections with basket cell (synapse $h$ ), $\mathrm{O} / \mathrm{A}$ interneuron (synapse i), and L/M interneuron (synapse r). Afferent fibers in stratum lacunosum-moleculare (L-M) make excitatory connections with pyramidal cell (synapse $u$ ) and $L / M$ interneuron (synapse $w)$. The greater efficacy of synapses on $L / M$ interneuron versus pyramidal cell results in $\mathrm{L} / \mathrm{M}$ interneuron feedforward aclivation. Ultrastructurally, synaptic contacts are also found on nonpyramidal dendrites in stratum lacunosum-moleculare (possibly synapses $t$ and v). Axons in stratum moleculare (M) of dentate gyrus make excitatory synapses on granule cell (synapse aa) and $\mathrm{L} / \mathrm{M}$ interneuron (synapse $\mathrm{bb}$ ).

Pyramidal cell axon makes excitatory synapses on basket cell (synapse b) and on O/A interneuron (synapse c). Pyramidal basket cell axon makes inhibitory synapses on pyramidal cell soma (synapse d). Ultrastructurally, synaptic contacts (possibly from basket cell collaterals) are made on nonpyramidal dendrites (synapse $\mathrm{s}$ on $\mathrm{L} / \mathrm{M}$ interneuron; synapse e on $\mathrm{O} / \mathrm{A}$ interneuron). $\mathrm{O} / \mathrm{A}$ interneuron axon makes inhibitory synapses on pyramidal cell soma (synapse j) and on basket cell (synapse k). $\mathrm{O} / \mathrm{A}$ interneuron axon makes synaptic contact with nonpyramidal dendrites in stratum oriens (possibly $\mathrm{L} / \mathrm{M}$ interneuron dendritc, synapse q). L/M interncuron axon makes inhibitory synapse with pyramidal cell (synapse $\mathrm{x}$ ) and stratum pyramidale interneuron (possibly basket cell, synapse y). Ultrastructurally, $\mathrm{L} / \mathrm{M}$ interneuron axon makes synaptic contact with dentate granule cells (synapse cc) and with other nonpyramidal neurons in $\mathrm{CA} 1$ region (possibly $\mathrm{O} / \mathrm{A}$ interneuron, synapse $\mathrm{z}$ ). Some of the morphologically suggested synapses (but yet undefined with paired intracellular recordings) could account for the IPSPs evoked in interneurons from stimulation of specific layers of hippocampus (synapses s, $\mathrm{q}$, and $\mathrm{v}$, for example).

As is evident from the diagram, the local circuitry of the hippocampus is proving quite complex. Future experiments should uncover an even greater complexity since many nonpyramidal cell types identified anatomically (Ramon y Cajal, 1911 ; Lorente de No, 1934; Somogyi et al., 1983) have yet to be identified physiologically. The fact that certain interneuron 

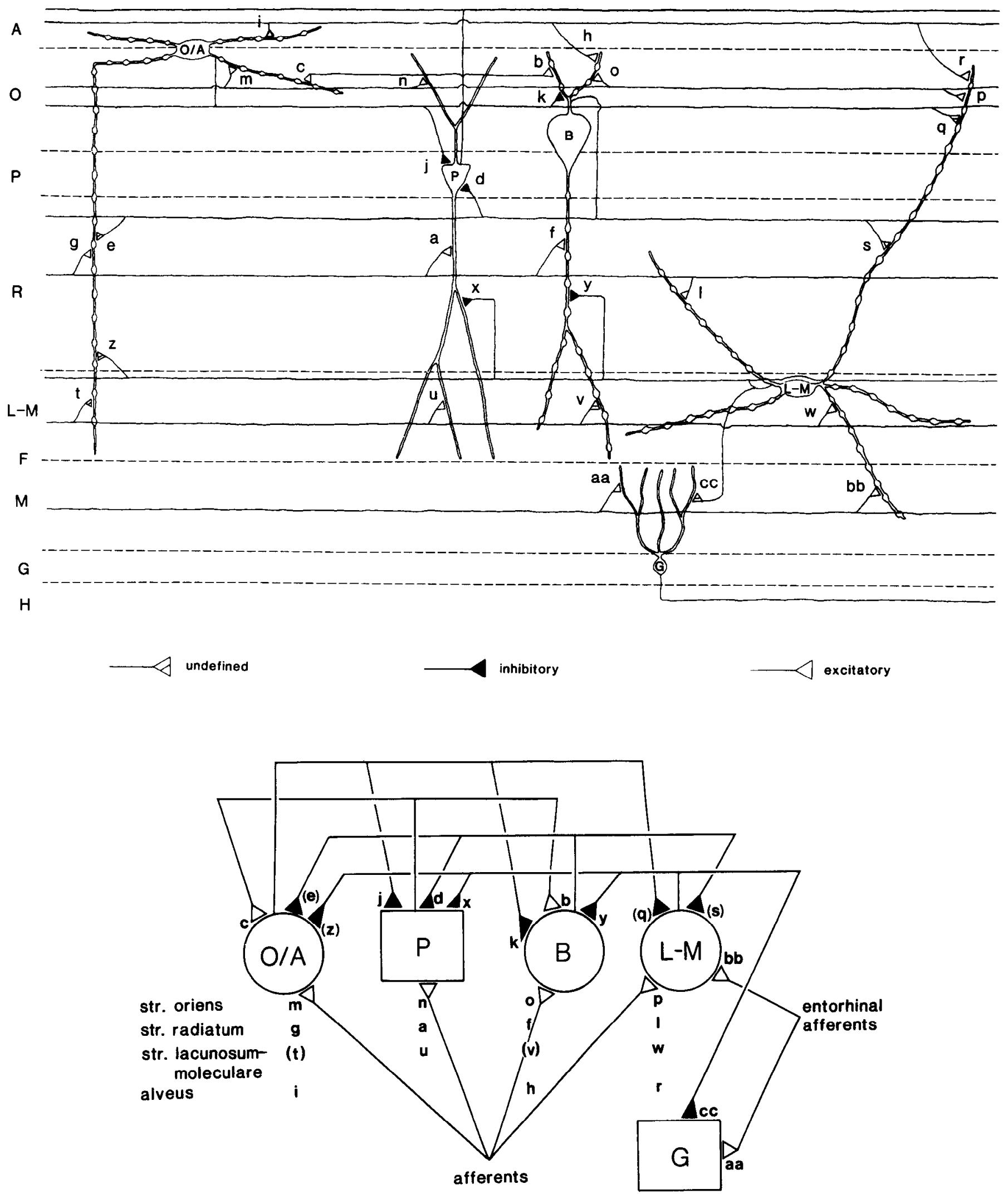

Figure 9. Summary local circuit diagrams. Top, Cartoon of neuronal circuitry of CA 1 region (alveus, $A$; oriens, $O$; pyramidale, $P$; radiatum, $R$; lacunosum-moleculare, $L-M$; hippocampal fissure, $F$ ) and dentate gyrus upper blade (moleculare, $M$; granule cells, $G$; hilus, $H$ ) based on our studies of physiologically identified CAl interneurons. Synapses that have not been demonstrated both electrophysiologically and morphologically are striped. Bottom, Simplificd block diagram of the same circuitry, with striped synapses shown in parentheses. See text for details. 
types innervate more than one region of the hippocampal formation adds another dimension to this complexity. However, using combined anatomical and physiological methods, we have shown that interneuron types can be characterized and their specific role in hippocampal circuitry determined. Such knowledge of the ever-increasing complexity of hippocampal circuitry should prove useful in assessing the contribution of circuit properties to normal hippocampal function and to pathological cases, such as epileptic discharges, that may involve abnormal circuit properties.

\section{References}

Alger, B. E. (1984) Characteristics of a slow hyperpolarizing synaptic potential in rat hippocampal pyramidal cells in vitro. J. Neurophysiol. 52: 892-910.

Alger, B. E., and R. A. Nicoll (1982a) Feed-forward dendritic inhibition in rat hippocampal pyramidal cells studied in vitro. J. Physiol. (Lond.) 328: 105-123.

Alger, B. E., and R. A. Nicoll (1982b) Pharmacological evidence for two kinds of GABA receptor on rat hippocampal pyramidal cells studied in vitro. J. Physiol. (Lond.) 328: 125-141.

Andersen, P., J. C. Eccles, and Y. Loyning (1964a) Location of postsynaptic inhibitory synapses on hippocampal pyramids. J. Neurophysiol. 27: 592-607.

Andersen, P., J. C. Eccles, and Y. Loyning (1964b) Pathway of postsynaptic inhibition in the hippocampus. J. Neurophysiol. 27:608619.

Andersen, P., G. N. Gross, T. Lømo, and O. Sveen (1969) Participation of inhibitory and excitatory interneurons in the control of hippocampal cortical output. In The Interneuron, M. B. Brazier, Ed., pp. 415-432, University of California Press, Berkeley.

Benardo, L. S., L. M. Masukawa, and D. A. Prince (1982) Electrophysiology of isolated hippocampal pyramidal dendrites. J. Neurosci. 2: 1614-1622.

Buzsaki, G., and E. Eidelbery (1982) Direct afferent excitation and long-term potentiation of hippocampal interneurons. J. Neurophysiol. 48: 597-607.

Finch, D. M., and T. L. Babb (1981) Demonstration of caudally directed hippocampal efferents in the rat by intracellular injection of horseradish peroxidase. Brain Res. 214: 405-410.

Frotscher, M., Cs. Léránth, K. Lübbers, and W. H. Oertel (1984) Commissural afferents innervate glutamate decarboxylase immunoreactive non-pyramidal neurons in the guinea pig hippocampus. Neurosci. Lett. 46: 137-143.

Gamrani, H., B. Ontoniente, P. Seguela, M. Geffard, and A. Calas (1986) Gamma-aminobutyric acid-immunoreactivity in the rat hippocampus. A light and electron microscopic study with anti-GABA antibodies. Brain Res. 364: 30-38.

Kandel, E. R., W. A. Spencer, and F. J. Brinley (1961) Electrophysiology of hippocampal neurons. I. Sequential invasion and synaptic organization. J. Neurophysiol. 24: 225-242.

Kawaguchi, Y., and K. Hama (1987) Two subtypes of non-pyramidal cells in rat hippocampal formation identified by intracellular recording and HRP injection. Brain Res. 411: 190-195.

Knowles, W. D., and P. A. Schwartzkroin (1981a) Local circuit interactions in hippocampal brain slices. J. Neurosci. 1: 318-322.

Knowles, W. D., and P. A. Schwartzkroin (1981b) Axonal ramifications of hippocampal CA l pyramidal cells. J. Neurosci. 1: 1236-1241.

Knowles, W. D., J. H. Schneiderman, H. V. Wheal, C. E. Stafstrom, and P. A. Schwartzkroin (1984) Hyperpolarizing potentials in guinea pig hippocampal CA3 neurons. Cell. Mol. Neurobiol. 4: 207-230.

Kunkel, D. D., A. E. Hendrickson, J. Y. Wu, and P. A. Schwartzkroin (1986) Glutamic acid decarboxylase (GAD) immunocytochemistry of developing rabbit hippocampus. J. Neurosci. 6: 541-552.

Kunkel, D. D., J.-C. Lacaille, and P. A. Schwartzkroin (1987) Morphology of lacunosum-moleculare interneurons in the CA1 region of guinea pig hippocampus. Neurosci. Abstr. 13: 1332.

Lacaille, J.-C., and P. A. Schwartzkroin (1988) Stratum lacunosummoleculare interneurons of hippocampal CA1 region. I. Intracellular response characteristics, synaptic responses, and morphology. J. Neurosci. 8: 1400-1410.

Lacaille, J.-C., A. L. Mueller, D. D. Kunkel, and P. A. Schwartzkroin (1987) Local circuit interactions between oriens/alveus interneurons and CA1 pyramidal cells in hippocampal slices: Electrophysiology and morphology. J. Neurosci. 7: 1979-1993.

Lorente de No, R. (1934) Studies on the structure of the cerebral cortex. II. Continuation of the study of the ammonic system. J. Psychol. Neurol. (Lpz.) 46: 113-177.

MacVicar, B. A., and F. E. Dudek (1980) Local synaptic circuits in rat hippocampus: Interactions between pyramidal cells. Brain Res. 184: 220-223.

Masukawa, L. M., and D. A. Prince (1984) Synaptic control of excitability in isolated dendrites of hippocampal neurons. J. Neurosci. 4: 217-227.

Milcs, R., and R. K. S. Wong (1984) Unitary inhibitory synaptic potentials in the guinea-pig hippocampus in vitro. J. Physiol. (Lond.) 356: $97-113$.

Newberry, N. R., and R. A. Nicoll (1985) Comparison of the action of baclofen with gamma-aminobutyric acid on rat hippocampal pyramidal cells in vitro. J. Physiol. (Lond.) 360: 161-185.

Ramon y Cajal, S. (1911) Histologie du Systeme Nerveux de l'Homme et des Vertebres, Maloine, Paris.

Ribak, C. E., J. E. Vaughn, and K. Saito (1978) Immunocytochemical localization of glutamic acid decarboxylase in neuronal somata following colchicine inhibition of axonal transport. Brain Res. 140:315332.

Roberts, G. W., P. L. Woodhams, J. M. Polak, and T. J. Crow (1984) Distribution of neuropeptides in the limbic system of the rat: The hippocampus. Neuroscience 2: 35-77.

Schwartzkroin, P. A. (1981) To slice or not to slice. In Electrophysiology of Isolated Mammalian CNS Preparations, G. Kerkut and H. Wheal, eds., pp. 15-50, Academic, London.

Schwartzkroin, P. A., and D. D. Kunkel (1985) Morphology of identified interneurons in the CAl regions of guinea pig hippocampus. J. Comp. Neurol. 232: 205-218.

Schwartzkroin, P. A., and L. H. Mathers (1978) Physiological and morphological identification of a nonpyramidal hippocampal cell type. Brain Res. 157: 1-10.

Skrede, K. K., and R. H. Westgaard (1971) The transverse hippocampal slice: A well-defined cortical structure maintained in vitro. Brain Res. 35: 589-593.

Somogyi, P., A. D. Smith, M. G. Nunzi, A. Gorio, H. Takagi, and J. Y. Wu (1983) Glutamate decarboxylase immunoreactivity in the hippocampus of the cat: Distribution of immunoreactive synaptic terminals with special reference to the axon initial segment of pyramidal neurons. J. Neurosci. 3: 1450-1468.

Somogyi, P., A. J. Hodgson, A. D. Smith, M. G. Nunzi, A. Gorio, and J. Y. Wu (1984) Different populations of GABAergic neurons in the visual cortex and hippocampus of cat contain somatostatin- or cholecystokinin-immunoreactive material. J. Neurosci. 4: 2590-2603.

Stewart, W. W. (1978) Functional connections between cells as revealed by dye-coupling with a highly fluorescent naphthalimide tracer. Cell 14: 741-759.

Tombol, T., M. Babosa, F. Hajdu, and G. Somogyi (1979) Interneurons: An electron microscopic study of the cat's hippocampal formation, II. Acta Morphol. Acad. Sci. Hung. 27: 297-313.

Wong, R. K. S., D. A. Prince, and A. I. Basbaum (1979) Intradendritic recordings from hippocampal neurons. Proc. Natl. Acad. Sci. USA 76: $986-990$. 